Article

\title{
Diversification and Local Embeddedness: The Rescaling of National New Area Governance in Post-Reform China
}

\author{
Li Wang ${ }^{1,2}$, Heng Chao ${ }^{1,3, *}$ and Guicai Li ${ }^{1,3}$ \\ 1 Shenzhen Graduate School, Peking University, Shenzhen 518055, China; wanglipku@163.com (L.W.); \\ ligc@pkusz.edu.cn (G.L.) \\ 2 College of Urban and Environmental Sciences, Peking University, Beijing 100000, China \\ 3 Laboratory for Urban Future (Shenzhen), Peking University, Shenzhen 518055, China \\ * Correspondence: chaoheng@pkusz.edu.cn; Tel.: +86-0755-2603-2319
}

Received: 15 October 2019; Accepted: 3 November 2019; Published: 6 November 2019

\begin{abstract}
In the rapidly growing literature on exploring urban restructuring in reference to the state rescaling, many authors have neglected the relatively fixed and immobile forms of territorial organization. The development of China's National New Areas (NNAs) provides an opportunity to explore the hybrid and multiscalar processes of state rescaling. From the perspective of rescaling, an analytical framework was established to examine the practice of NNAs and their governance rescaling in China. Every National New Area (NNA) is the result of China's "state spatial selectivity", and the central government has guided policies to a specific spatial scale to cope with the development crisis. The rescaling of NNA governance is the process of the functioning of all-level administrative subjects in the functional orientation, spatial zoning, administrative system, and power allocation through rigid or flexible means. In practice, there are significant governance scale differences in territorial spatial organization, administrative systems, and power distribution among the various NNAs, which has led to diverse governance modes. The degree of coupling between the scale of new and existing administrative divisions is the key to the rescaling of NNA governance. Most NNAs are still facing the challenge of unifying their territorial development logic. Discussions of state rescaling in western countries have focused on the super-local level. The case of China clearly shows the role of local embeddedness and diversification in rescaling.
\end{abstract}

Keywords: rescaling; National New Area; governance; diversification; local embeddedness; China

\section{Introduction}

Since the 1980s, influenced by globalization and neoliberalization [1], countries around the world have carried out different forms of state spatial restructuring to maintain and strengthen competitive regions [2,3]. The rescaling of state power has been observed not only in Western advanced economies across the Atlantic but also in countries of the Far East across the Pacific inclusive of China undergoing profound social and economic transformation [4]. Since the reform and opening-up period, the evolution of China's regional development policy has also been guided by an objective and timely reflection of the economic globalization trend by the state and local governments [5]. Through strategic regional rescaling and "gradients" of differential institutional supply, state/local power acts over different spatial ranges, triggering the restructuring of spatial organizations and forms of governance at different scales to achieve exponential growth. This trend has resulted in a revival of regional research. How to improve the institutional basis of regional development, cultivate regional competitiveness, and accumulate wealth has become the focus of "new regionalism" research [6]. In recent years, rescaling as a product of administrative restructuring, spatial production strategy, and regional restructuring 
has become an important perspective in the new regionalism concept when exploring globalization, regional spatial production, and regional governance, and many successes have been achieved [7-10]. The concept of rescaling provides a powerful meta-theoretical tool for understanding the changing scale of governance [11]. State spatial selectivity theory originated from state rescaling processes that operated in different forms, ranging from regional management agency to soft regional planning and policy space [12,13].

Although studies based on the perspective of rescaling have made significant contributions to our understanding of the nature, dynamics, and effects of geographical-scale construction, several issues remain controversial and unclear. The term rescaling originated from a social science perspective. It is not clear how the popular practice of rescaling changes temporally and spatially, and how state rescaling is embedded in local. State rescaling as an over-abstracted regulatory approach is associated with state power and the crisis tendencies of capitalism resulting in an over-structural generalization [14]. The neglect of the local context and social actors has led to widespread criticism when considering the diversity of national scale reconstruction and the inadequacy of local embedding processes $[15,16]$. In addition, previous literature based on western reality and background has revealed that the state is under pressure to adopt a strategy of rescaling for the sake of enterprises and the public [17]. Previous work has focused on the relationship between the state and nonstate sectors, while the complex intergovernmental relationships and conflicts in the process of rescaling and their impact on the results have not received sufficient attention. When applied to a political economy, where the state should not be regarded as a monolithic whole, with consistent interests and concerns, state organizations are fragmented into various actors with conflicting interests [18]. Therefore, it is of great significance to investigate the process and results of state rescaling based on location and local conditions, and to further examine its real development process and diversification consequences [19].

In recent years, the vigorous development of the National New Area (NNA) strategy, which has been carefully planned by the central government of China, has provided a valuable opportunity to investigate some important unsolved issues in the existing literature. In the "new normal", NNAs are recognized as a new round of state strategic rescaling in China, with the aim of promoting economic growth in specific regions and regionally coordinated development [20]. The NNA governance structure has developed according to the rescaling projects, the process of restructuring, and the extent of government and social power at different scales, which has influenced the effectiveness of NNAs. Studies of the reallocation of state power in China have highlighted the unique characteristics and national background of the rescaling process [21]. Chinese case studies have proven that the essence of state rescaling is the state compulsory purchase process, which is related to the redistribution of state power [22]. Although the central government plays an important role in state rescaling, it is not the only participant in the process. In a study of the state practice of establishing the recent NNAs, it clearly showed that both the central and local governments were actively involved and the complex relationship within local governments introduced many uncertainties into their development [23]. In the "new normal", China's state rescaling represents a bargaining strategy for local authorities to expand their resources and policy empowerment [24]. The practices inspired by the umbrella policy and policy innovations of the NNA only impacted on new practices in rural land development and commercialization, while the NNAs did not deal with the land-centered development crisis in China [25]. Although the diversity of rescaling and the practical complexity of intergovernmental relationships are recognized in China, there is still a lack of in-depth analysis and a wider comparison of the diversification and local embeddedness of rescaling. Compared with the previous literature on the vigorous development of regional planning and the results of state rescaling at the regional level [10,26-29], NNA has not been given enough attention.

This study investigated the local embedding characteristics and diversification of the rescaling of NNA governance in post-reform China. This paper had two specific aims: (1) to expand the analytical framework of rescaling at the micro level; and (2) to provide support for the optimization of the governance structure and improve the governance capacity of China's NNAs. After the introduction, 
the structure of this paper is as follows. First, the analytical framework of this study is constructed from the perspective of rescaling. Second, the spatial and temporal characteristics of the establishment of the NNAs are briefly explained. Third, the local embedding characteristics and diversification of the rescaling of NNA governance are analyzed. Furthermore, this paper also discusses the key factors and challenges influencing the rescaling of NNA governance. Finally, the important results of the study are summarized.

\section{Research Methodology}

\subsection{Space, Scale, and Rescaling}

The New Marxist School introduced relevant theories of political economics into the study of urban and regional development. The theories hold that the mode of production in the era of globalization makes capital and power the main driving force of urban and regional evolution [30]. From this point of view, spatial research has a strong "social turn" and produces theories such as the post-modern space concept and the production of space [31-33]. The concept of "scale" is rooted in this background and has gradually become a measure of spatial scale, order, hierarchy, and social relationships. Starting from the concept of scale, rescaling refers to the change of power and control of power over different scales [34-37]. It not only represents the construction of a new scale and the decomposition of the old scale but also implies a social dynamic process of governance. Therefore, rescaling is usually used in the context of deterritorialization and reterritorialization in the globalization process [38]. It not only reflects the intent to construct a specific territorial organization but is also regarded as a spatial production strategy that is conducive to capital accumulation [39]. As an analytical concept, rescaling aims to deepen the analysis and recognition of the space-power-system relationship and other elements involved in the existing scale through the construction and investigation of a new scale.

Brenner divided rescaling into urban rescaling and state rescaling based on a "state-city" analysis framework, in which state rescaling will promote the emergence of supranational regions, subnational regions, and emerging industrial areas [7]. Shen reported that rescaling reflects the central government's power intervention in the active regulation of local development, including both upward and downward power shifts [40]. Horak stated that rescaling has been transformed into a strategy to serve specific goals, and local institutional and political factors play an important role [41]. In the existing research, rescaling has mainly focused on two aspects: (1) an exploration of the impact and mechanisms of the mode of production and organization of globalization on territorial organization at different scales (e.g., national, regional, and city); and (2) investigations of the rescaling strategies adopted by different territorial organizations to meet the challenges of globalization. This involves investigations of scale type, power allocation, scale role, scale politics, and other factors. In recent years, many scholars have promoted the application of rescaling theory in a nonwestern context [9]. In China, the administrative entity has also experienced state rescaling through decentralization and deregulation, and the decentralization of power and multiscale characteristics are also prevalent in the implementation of regional dimension projects [42]. The difference is that China's "city-regional" governance still has the central government characteristics of "top-down" and "control". Major power changes could restructure territorial units or change the size of cities and lead to a fragmentation of internal management [43].

In summary, rescaling involves a space-subject-power relationship in addition to other elements, providing an important perspective for analyzing the "production" of a specific territorial organization and the rescaling of their governance. There are two factors that must be recognized prior to any study of NNA governance. First, China's state power still plays an important role in changing the developmental structure of the "city-region." Second, the power rescaling undertaken by the central government symbolizes not only the decentralization and deregulation of state power but also the re-centralization and restoration of state power in specific regions, forming a multilevel governance structure. In this study, we follow the Chinese official definition, documents, plans, statistical data, and interviews of the NNAs. These materials are gathered from four main sources: (1) official 
documents issued by the State Council of China; (2) official Websites of 19 NNAs; (3) master plans and statistical bulletins of 19 NNAs; (4) interviews with local planners and officials in 10 NNAs from 2013 to 2017 .

\subsection{Construction Logic of the Governance Scale of NNAs}

China's NNAs are large-scale and comprehensive urban functional zones approved by the State Council, which are based on relevant administrative and functional zones and undertake the strategic tasks of national development and reform and opening-up [20]. As a special policy space approved by the central government, the establishment and development of an NNA is a process of rescaling, which involves positioning adjustment, division reconstruction, and the adjustment of administrative systems and power relationships among administrative bodies at all levels (central government, provincial government, municipal government, and district/county government). Based on the perspective of rescaling, the construction of NNA governance scale is a process in which administrative bodies at all levels change their functions, spatial zoning, administrative systems, and power allocation through rigid or flexible means (Figure 1). As a result, a new cross-border joint territorial organization has been formed in the structure of NNAs, and several existing territorial organizations, with different scales and cross-administrative boundaries, have been superimposed on each other. The governance scale constructed by an NNA is uncertain and dynamic.

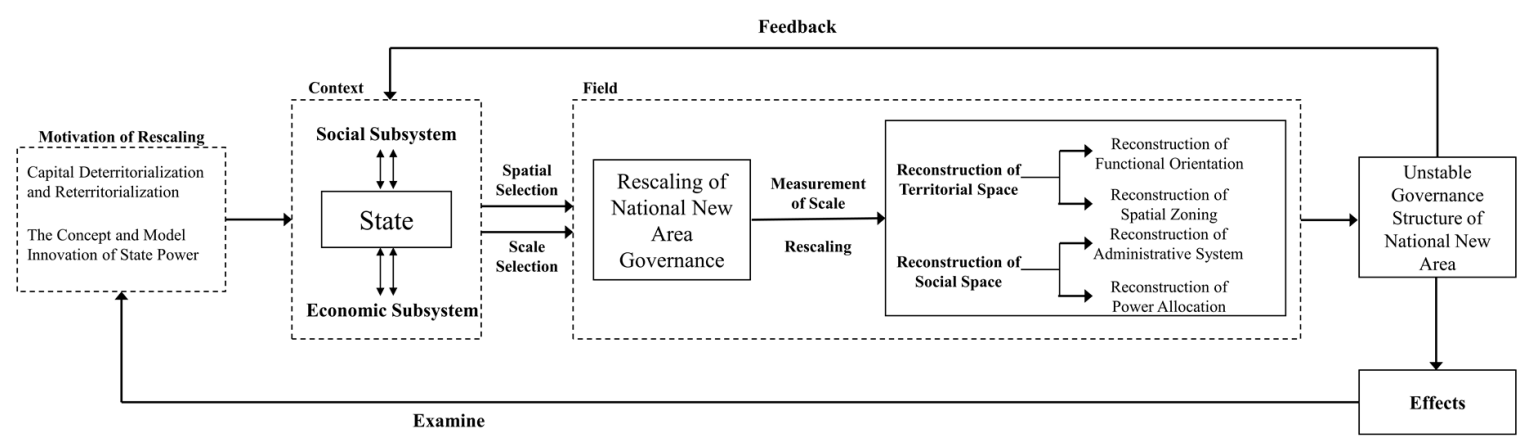

Figure 1. Flowchart of the rescaling of National New Area (NNA) governance.

Under the background of globalization, the macro-motives for the establishment and development of NNAs are capital deterritorialization and reterritorialization, as well as innovative concepts and modes of state power. Therefore, the institutional supply, policy support, and authority given by the central government give "legitimacy" to the construction of the NNA governance scale. The aim is to enhance the governance capacity of NNAs so that they can better attach to mobile global capital. However, under the current governance system in China, each administrative unit has a territoriality logic to safeguard its own developmental interests, i.e., the demand for the development of their respective jurisdictions and the specific strategy choices [44,45]. Therefore, whether the rescaling of NNA governance can achieve the unity of territoriality development logic, i.e., reduce the conflicts and contradictions between the new and the existing governance subjects, will determine the level of its governance efficiency. However, inefficient governance may make it impossible for the development and construction of NNAs to form a synergistic force that attracts investment; thus, making it difficult to achieve the goal of promoting economic growth and leading regional coordinated development.

\section{China's NNAs: Contextual Analysis and Spatial-Temporal Characteristics}

As a regional space production strategy, rescaling results in "temporary" and "non-fixed" adjustments and choices in the spatial field, which means that a permanent dominant scale does not exist. To attain dominance or scale convergence, each space will compete dynamically [46]. This shows that the NNA is a dynamic process of social construction, and the combination of spatial scales is always controversial and constantly reconstructed [47]. 


\subsection{Temporal Characteristics of China's NNAs}

The first NNA in China, Shanghai Pudong New Area, was established in 1992, and the second, Tianjin Binhai New Area, was established in 2006. Since 2010, the approval of NNAs has accelerated significantly. By the end of 2017, the number of NNAs had reached 19. Official documentation shows that the establishment of the national strategic assessment system is cyclical and essentially a temporary state intervention based on different national aspirations, motivations, and strategic considerations. The existing NNAs have been established under different international economic backgrounds and national development periods, which can be basically divided into four stages (Table 1).

Table 1. Periodicity of the establishment of National New Areas (NNAs).

\begin{tabular}{|c|c|c|c|}
\hline Period & $\begin{array}{l}\text { International } \\
\text { Background }\end{array}$ & Domestic Background & State-Directed Visions \\
\hline $\begin{array}{l}\text { Period I: } 1980 \text { s to early } \\
\text { 1990s }\end{array}$ & $\begin{array}{l}\text { Capital globalization and } \\
\text { global trade system }\end{array}$ & Opening-up of the coastal area & $\begin{array}{l}\text { The frontier of integrating into } \\
\text { globalization; regional growth } \\
\text { pole; promoting the coastal } \\
\text { opening-up }\end{array}$ \\
\hline $\begin{array}{l}\text { Period II: } 1990 \text { s to early } \\
\text { 2000s }\end{array}$ & $\begin{array}{l}\text { New opportunities due } \\
\text { to globalization }\end{array}$ & $\begin{array}{l}\text { Entry into the WTO; eastern-led } \\
\text { development strategy }\end{array}$ & $\begin{array}{l}\text { Independent innovation; } \\
\text { international competitiveness; } \\
\text { regional growth pole }\end{array}$ \\
\hline Period III: 2000s to 2012 & Global financial crisis & $\begin{array}{l}\text { Expanding domestic demand; } \\
\text { balanced development of the } \\
\text { eastern, central, and western } \\
\text { regions of China }\end{array}$ & $\begin{array}{l}\text { Regional growth pole; promoting } \\
\text { the development of central cities } \\
\text { and urban agglomerations; } \\
\text { optimizing the regional } \\
\text { development pattern }\end{array}$ \\
\hline Period IV: 2012 to present & $\begin{array}{l}\text { Post-Financial Crisis; } \\
\text { economic globalization } \\
\text { adjustment }\end{array}$ & $\begin{array}{l}\text { New normal; economic transition; } \\
\text { "one belt and one road"; } \\
\text { comprehensive opening-up and } \\
\text { regional harmonious } \\
\text { development. }\end{array}$ & $\begin{array}{l}\text { Regional growth pole; opening-up } \\
\text { window; exploring innovative } \\
\text { development and green } \\
\text { development }\end{array}$ \\
\hline
\end{tabular}

Source: compiled by the author from State Letter (1992-2017) documents regarding the approval of the State Council for the establishment of an NNA.

In the early 1990s, the globalization of capital and a global trade system were established, and China also proposed the opening-up of its eastern coast. In 1992, the central government established the Shanghai Pudong New Area to better introduce global capital, speed up integration into globalization, and through the rapid development of Pudong New Area and other reform experiments, promote the full opening-up of the Yangtze River Delta region [48]. At the initial stage of the establishment of Pudong New Area, its functions mainly focused on finance, shipping, and high-level international manufacturing industries, with a focus on the construction of Lujiazui CBD, a bonded zone, Jinqiao Development Zone, and an airport and container port. Since 2000, Pudong New Area's functions have shifted to the transformation and upgrading of high-end manufacturing, commerce and trade, scientific and technological innovation, and service industries, and it has always been at the forefront of international exchanges.

After the financial crisis in 1997, new opportunities emerged due to globalization. Under the influence of the third scientific and technological revolution, modern manufacturing industry has a global layout. Tianjin Binhai New Area was established in 2006 to exploit the new opportunities offered by globalization, especially the new layout of modern manufacturing industry. The central government expected the Binhai New Area to promote the independent innovation of Chinese manufacturing industry, enhance its international competitiveness, and promote the development of Beijing-Tianjin-Hebei through the Binhai New Area [49]. The functional focus of Binhai New Area is high-end heavy manufacturing industry and national strategic industries that undertake transnational cooperation. Under the background of global equipment manufacturing industry transfer, Binhai New Area has attempted to promote the breakthrough of national strategic industries by introducing, absorbing, and transforming novel technologies. 
After the 2008 financial crisis, in response to changes in the international and domestic development environment, China made major adjustments to its development path and economic structure, and its spatial strategy gradually shifted to inland, central western, and northeastern regions. At the same time, based on the need for macro-control, regional coordinated development, and the stimulation of domestic development momentum, from 2010 to 2012, the central government established Chongqing Liangjiang New Area, Zhejiang Zhoushan Archipelago New Area, Gansu Lanzhou New Area, and Guangzhou Nansha New Area to cope with the international financial crisis, cultivate new regional growth poles, and promote the relatively balanced development of eastern, central, and western regions.

In 2014, the number of NNAs increased dramatically, and by 2017 thirteen more NNAs were added, nine of which were established in western and central China. On the one hand, central government strengthened the role of NNAs as regional growth poles to stabilize economic growth and promote regional coordinated development, while on the other hand, central government required NNAs to conduct innovative development path experiments to find solutions to development challenges. Since the tax-sharing system reform in 1992, local government used a land-centered development model [50], resulting in more social, economic, and ecological problems while achieving rapid economic growth [51,52]. Since the 18th National Congress of the Communist Party of China in 2012, President Xi Jinping has called for innovation and green development. Innovation experiments, green development, and intensive use of natural resources, such as land, are prerequisites for NNAs. The recent reform of spatial planning promoted by the State Council represents the tightening policy background of local land development [27]. This has also stimulated the enthusiasm of local governments to apply for NNA.

\subsection{Spatial Characteristics of China's NNAs}

The spatial distribution of NNAs is consistent with the spatial strategy of national regional development, which has become the key to regional development and construction, and represents the spatial logic and direction of China's reform and opening-up. It is mainly manifested in the following two features (Figure 2): (1) from the south to the north, from the east to the west, and from the coast to the inland; and (2) from the single point layout to the overall development of the spatial pattern. In the process of China's rapid economic development, the establishment of NNAs has played a vital role. From Shenzhen Special Economic Zone to Shanghai Pudong New Area, and then to Tianjin Binhai New Area, China's economy has moved from recovery to prosperity. It can be said that the 40 years of reform and opening-up have been 40 years of gradual development of China's coastal areas from the south to north. The coastal development path represents the spatial logic of China's 40 years of reform and opening-up. After entering the 21st century, China began to implement the strategy of developing the western region. In 2010, Chongqing Liangjiang New Area was established, which was the first NNA established in the western region. The spatial path of China's reform and opening-up was pushed forward from the eastern coast to the western region. Since 2014, the establishment of Jinpu New Area has formally filled the gap in northeast China. In 2015, the Xiangjiang New Area was part of the "one belt and one road" strategy which became the central region's national strategy. Generally speaking, the development sequence and distribution of the NNAs followed the spatial sequence evolution law of "east-west-northeast-central".

At the same time, the spatial distribution of NNAs also follows the fixed rules of "one province or city only corresponds to an NNA". However, there is more than one NNA in the larger regions. At present, the number of NNAs is eight in the eastern region, six in the western region, three in the northeast region, and two in the central region. This distribution represents not only the spatial superposition of NNAs but also expands the scope of their spatial distribution. It represents an advance along the whole coastal area, with a multipoint layout in western and northeastern areas, and a stride forward from single-point driven regional development to a comprehensive layout in the territorial area and spatial pattern of regional linkage development. The spatial "densification" 
of NNAs may eventually face the challenges of a shrinking hinterland and intensifying competition among regions [53-55].

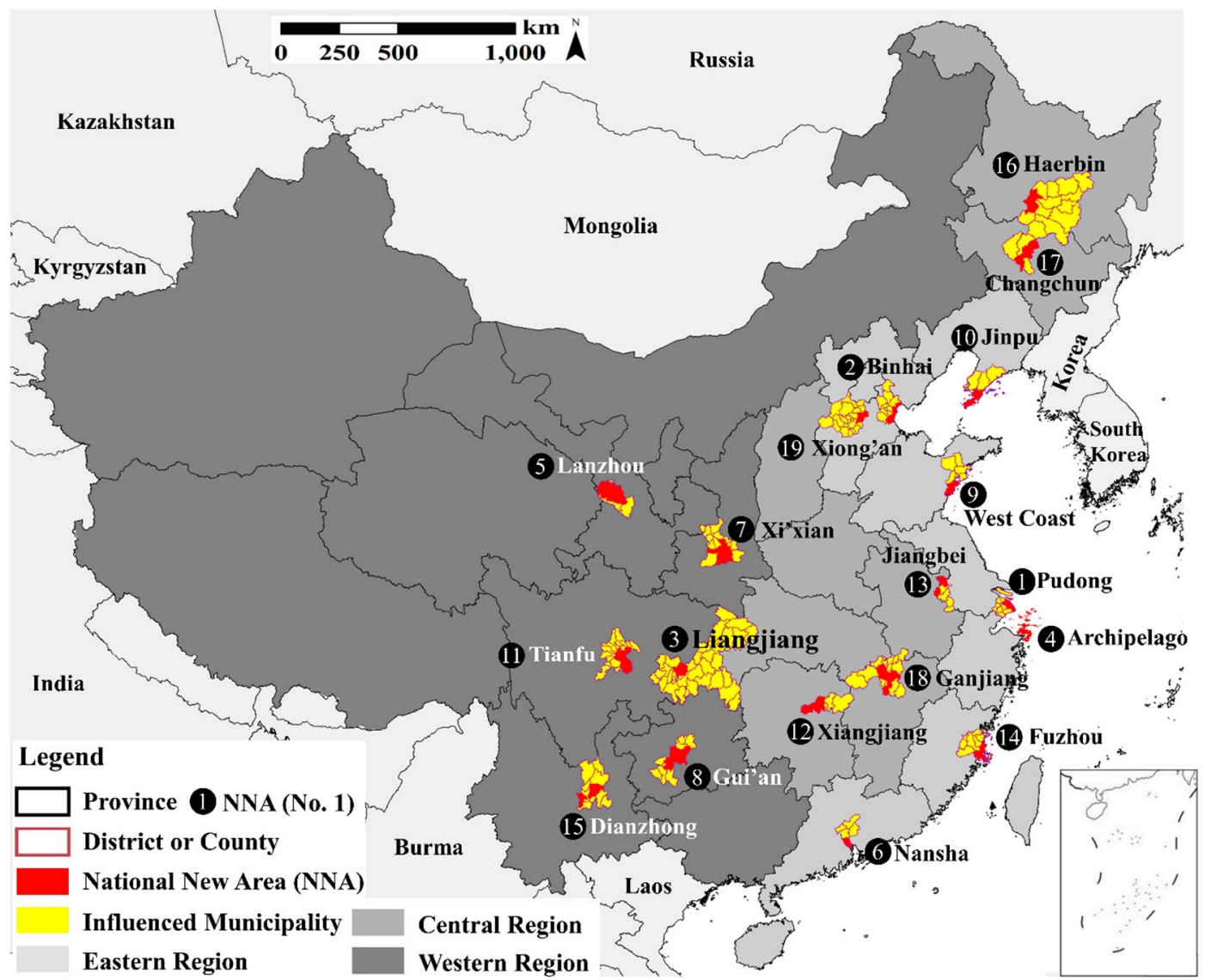

Figure 2. Spatial characteristics of China's National New Areas (NNAs).

\section{The Rescaling of China's NNA Governance}

\subsection{Reconstruction of Functional Orientation}

As an important part of the national spatial strategy, the establishment of NNAs aims to enhance national competitiveness and implement the national major development and reform strategy [20]. Functional positioning represents the central government's expectations for the development goals of the NNAs, highlighting the redistribution of social resources, such as policies, funds, and the right to development at different spatial scales (Table 2). This also means that the central government embeds important functions into local development. The NNAs have been entrusted with several important missions, such as "leading innovation, future reform, increasing economic activity, expanding openness, and coordinating urban and rural areas", which symbolizes the central government's transfer of power to the local scale. Local governments usually integrate the functions of NNAs into urban planning to form a spatial growth pole within the region. The urban planning of an NNA reveals the development strategy of local governments, i.e., to serve the goal of local economic growth through strategic national projects. As a result, the establishment and approval of NNAs also indicate that the function of local urban areas has developed a national significance. 
Table 2. State-directed visions of National New Areas (NNAs).

\begin{tabular}{|c|c|c|c|}
\hline Name & Approval Date & Planning Area $/ \mathrm{km}^{2}$ & State-Directed Vision \\
\hline Pudong & June 1990 & 1210 & $\begin{array}{l}\text { Comprehensive reform, core area of the } \\
\text { "Four Centers" strategy }\end{array}$ \\
\hline Binhai & May 2006 & 2270 & $\begin{array}{l}\text { International shipping center in the north, } \\
\text { international logistics center, eco-city }\end{array}$ \\
\hline Liangjiang & May 2010 & 1200 & $\begin{array}{l}\text { Inland opening up, financial and economic } \\
\text { center in the upper reaches of the Yangtze } \\
\text { River }\end{array}$ \\
\hline Archipelago & June 2011 & 1440 & $\begin{array}{l}\text { Marine economic development, marine } \\
\text { economic growth pole in the Yellow River } \\
\text { Delta }\end{array}$ \\
\hline Lanzhou & August 2012 & 806 & $\begin{array}{l}\text { Growth pole in northwest China, strategic } \\
\text { platform for industrial transfer }\end{array}$ \\
\hline Nansha & January 2012 & 803 & $\begin{array}{l}\text { Quality living circle for Guangdong, Hong } \\
\text { Kong, and Macau, world-class service } \\
\text { center }\end{array}$ \\
\hline Xi'xian & January 2014 & 882 & $\begin{array}{l}\text { Western development hub, new engine for } \\
\text { developing the west }\end{array}$ \\
\hline Gui'an & January 2014 & 1795 & $\begin{array}{l}\text { Economic growth pole in western China, } \\
\text { inland opening up, ecological civilization }\end{array}$ \\
\hline West Coast & June 2014 & 2096 & $\begin{array}{l}\text { Marine science and technology innovation, } \\
\text { marine economic cooperation }\end{array}$ \\
\hline Jinpu & June 2014 & 2299 & $\begin{array}{l}\text { Northeast opening up, rejuvenating China's } \\
\text { northeastern industrial base }\end{array}$ \\
\hline Tianfu & October 2014 & 1578 & $\begin{array}{l}\text { Inland opening up, livable city, high-end } \\
\text { modern industry, urban-rural coordination }\end{array}$ \\
\hline Xiangjiang & April 2015 & 490 & $\begin{array}{l}\text { Improving central China, innovation-driven } \\
\text { development, building modern service } \\
\text { industry and cultural industry }\end{array}$ \\
\hline Jiangbei & June 2015 & 788 & $\begin{array}{l}\text { Fulcrum for the Yangtze River Economic } \\
\text { Belt and Yellow River Delta, growth pole in } \\
\text { Nanjing metropolis and Sunan area }\end{array}$ \\
\hline Fuzhou & September 2015 & 800 & $\begin{array}{l}\text { Fulcrum for cross-strait cooperation, } \\
\text { important portals for expanding opening } \\
\text { up, important modern industrial bases } \\
\text { along the southeastern coast }\end{array}$ \\
\hline Dianzhong & September 2015 & 482 & $\begin{array}{l}\text { Fulcrum for China's radiation into South } \\
\text { Asia and Southeast Asia, Growth pole in } \\
\text { Yunnan }\end{array}$ \\
\hline Harbin & December 2015 & 493 & $\begin{array}{l}\text { Fulcrum for China-Russia comprehensive } \\
\text { cooperation, new economic growth pole in } \\
\text { northeast China }\end{array}$ \\
\hline Changchun & February 2016 & 499 & $\begin{array}{l}\text { Engine for the new round of northeast } \\
\text { revitalization, Platform for the regional } \\
\text { cooperation and development of Tumen } \\
\text { River }\end{array}$ \\
\hline Ganjiang & October 2016 & 465 & $\begin{array}{l}\text { Fulcrum for the rise of the central region } \\
\text { and to promote the development of the } \\
\text { Yangtze River economic belt }\end{array}$ \\
\hline Xiong'an & April 2017 & 1770 & $\begin{array}{l}\text { An important pole of the } \\
\text { Beijing-Tianjin-Hebei world-class urban } \\
\text { agglomeration }\end{array}$ \\
\hline
\end{tabular}

Source: compiled by the author from the master plans of each NNA.

From a practical perspective, the functional orientation of the NNAs also has an obvious spatial and temporal heterogeneity. The NNAs approved by the central government at different times have different functions. The early establishment of Pudong New Area and Binhai New Area was based on a consideration of capital globalization and the establishment of the global trading system. Their functions were focused on leading the opening-up process, introducing global capital, 
and accelerating the integration into the global market. In recent years, facing a more complex domestic and international development environment, the functions of the NNAs have become more diversified. While emphasizing the strategic tasks of innovation, reform, and opening-up, they have also given more attention to the functions of regionally coordinated development, urban-rural integration, and ecological/green development to improve the quality of development. Based on the different geographical locations and development situations, the functional orientation of the NNAs also has obvious differences. For example, the functional orientation of Lanzhou New Area, which located in northwest China, is to build an important economic growth pole, an important national industrial base, an important strategic platform for opening up in the west, and a demonstration area for undertaking industrial transfer in northwest China [56]. The Nanjing Jiangbei New Area in the Yangtze River Basin is an important platform for the modern industrial agglomeration area in the Yangtze River Delta and the opening-up and cooperation of the Yangtze River Economic Zone [57]. The Nansha New Area is a demonstration area for the construction of high-quality living in Guangdong-Hong Kong-Macao, a pilot area for exploring a new urbanization mode, a pilot area for innovative social management, and also forms a convergence area with the business environment of Hong Kong and Macao [58]. It can be seen that the reform of systems and mechanisms, and expansion due to opening-up have gradually become the key tasks of NNAs.

\subsection{Reconstruction of Spatial Zoning}

The scale of upward and downward power movements around the functional orientation of NNAs is not "floating" or "nihility," but must be attached to a specific geographical space. Therefore, the reconstruction of spatial regionalization is not only the foundation for the establishment of NNAs but also the first step in breaking up the existing areas and realizing a social space construction characterized by "multiscale, multisubject, and overlapping" characteristics. According to the different types and quantities of existing administrative divisions involved in division reconstruction, NNAs can be divided into "prefecture-district type", "prefecture-county type", and "prefecture-prefecture type" (Figure 3). "Prefecture-prefecture type" means that the spatial scope of the NNA has exceeded the administrative boundary of a single prefecture-level city, and crossed at least two prefecture-level cities. This type of NNA is composed of municipal districts within different prefecture-level cities and municipal counties (or county-level cities). "Prefecture-county type" means that an NNA located in the administrative region of the same municipality directly under the central government or prefecture-level city administration, but its spatial scope covers at least one municipal county or county-level city. "Prefecture-district type" refers to an NNA in the same municipality directly under the central government or prefecture-level city within the administrative region, and its spatial scope is composed of all municipal districts. In recent years, with the increasing number of NNAs, the "prefecture-prefecture type" NNA, which breaks the administrative boundary between prefecture-level cities, has gradually become normal.

From the perspective of the division of internal space, unlike the industrial development in the early development zones and the need to attract foreign investment, the current NNAs have diverse economic functions. To conduct these economic functions, the interior of the NNA is divided into many functional and policy zones. For example, to support the functional orientation desired by the central government, the internal zones of Liangjiang New Area have been divided into a bonded port area, industrial park, ecological new town, financial and commercial area, and free trade pilot area (Figure 4). Among these areas, Lianglu-Cuntan Bonded Port Area has bonded warehousing, logistics, commodity display, and trade functions; Liangjiang Industrial Park is committed to developing advanced manufacturing and equipment manufacturing industries; Jiangbeizui CBD is positioned as the financial center in the upper reaches of the Yangtze River; Yuelai New Town includes exhibition, ecology, science and technology, and other functional sectors as part of a free trade experiment; and the Free Trade Zone has a focus on building high-end industry and a high-end factor agglomeration zone. The division of internal space in NNAs has been constantly adjusted throughout their development 
process. With the enhancement of the economic strength of the NNA, it constantly absorbs and integrates the surrounding areas, forming a reconstruction of the internal space that is driven by the agglomeration of economic factors. Policy adjustments made by the central government have also led to the reconstruction of the internal space of NNAs.
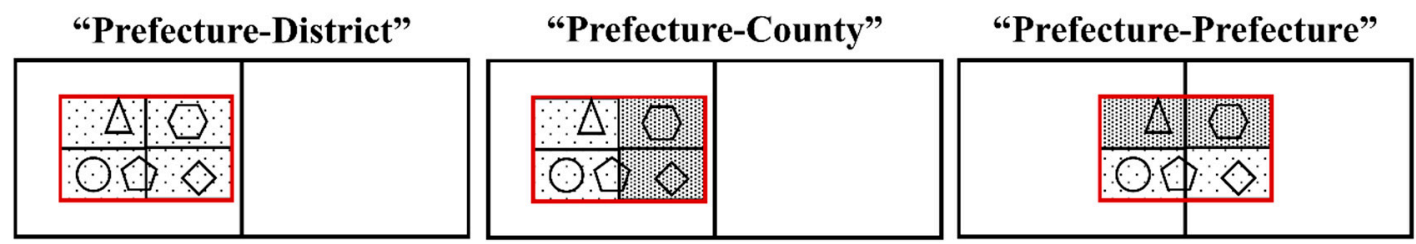

Prefecture-level City or Municipality Directly under the Central Government

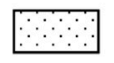

Municipal District

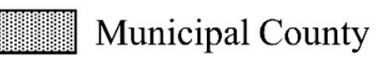
National New Area (NNA)

\section{$\triangle$ Industrial Zone $\bigcirc$ Bonded Zone $\bigcirc$ Ecological New Town}

Science \& Technical New Town

Financial Function Zone

Figure 3. Reconstruction of the spatial zoning of National New Areas (NNAs).

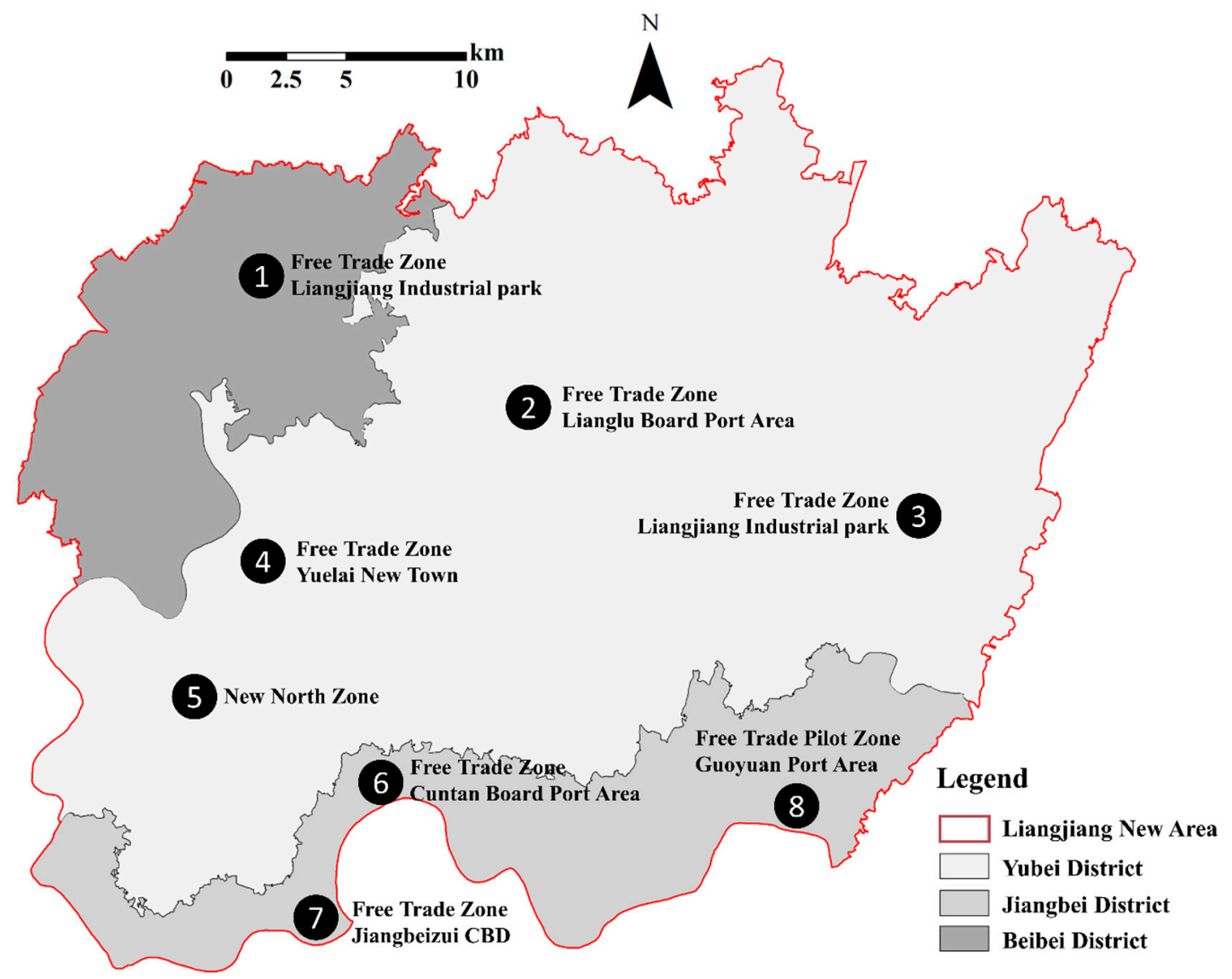

Figure 4. Functional zones of Chongqing Liangjiang New Area. Source. Author compiled from interviews in the fieldwork (2013-2016) with local planners, officials, and information derived from the master plan of Liangjiang New Area (2010-2020). 


\subsection{Reconstruction of the Administrative System}

In addition to reconstructing the territorial space, the NNAs have also reconstructed the relationship between the administrative systems operating within their jurisdiction, which have constantly been adjusted during the process of development. During the period from January 2010 to December 2016, the administrative systems operated within the NNAs can be divided into "territorial government" and "management committee" modes (Table 3).

Table 3. Management modes of National New Areas (NNAs).

\begin{tabular}{|c|c|c|c|c|}
\hline $\begin{array}{l}\text { Management } \\
\text { Mode }\end{array}$ & Management Type & Spatial Division & City & NNA \\
\hline \multirow[b]{2}{*}{$\begin{array}{c}\text { Territorial } \\
\text { government }\end{array}$} & $\begin{array}{l}\text { New district } \\
\text { government }\end{array}$ & Prefecture-District & $\begin{array}{l}\text { Shanghai } \\
\text { Tianjin }\end{array}$ & $\begin{array}{l}\text { Pudong } \\
\text { Binhai }\end{array}$ \\
\hline & Joint office & $\begin{array}{l}\text { Prefecture-District } \\
\text { or } \\
\text { Prefecture-County }\end{array}$ & $\begin{array}{c}\text { Zhoushan } \\
\text { Guangzhou } \\
\text { Qingdao } \\
\text { Dalian }\end{array}$ & $\begin{array}{c}\text { Archipelago } \\
\text { Nansha } \\
\text { West Coast } \\
\text { Jinpu }\end{array}$ \\
\hline \multirow{3}{*}{$\begin{array}{l}\text { Management } \\
\text { committee }\end{array}$} & $\begin{array}{c}\text { Management } \\
\text { committee I }\end{array}$ & Prefecture-District & $\begin{array}{l}\text { Chongqing } \\
\text { Nanjing } \\
\text { Haerbin } \\
\text { Changchun }\end{array}$ & $\begin{array}{l}\text { Liangjiang } \\
\text { Jiangbei } \\
\text { Haerbin } \\
\text { Changchun }\end{array}$ \\
\hline & $\begin{array}{l}\text { Management } \\
\text { committee II }\end{array}$ & Prefecture-County & $\begin{array}{l}\text { Lanzhou } \\
\text { Changsha } \\
\text { Fuzhou } \\
\text { Kunming } \\
\text { Baoding }\end{array}$ & $\begin{array}{c}\text { Lanzhou } \\
\text { Xiangjiang } \\
\text { Fuzhou } \\
\text { Dianzhong } \\
\text { Xiong'an }\end{array}$ \\
\hline & $\begin{array}{l}\text { Management } \\
\text { committee III }\end{array}$ & Prefecture-Prefecture & $\begin{array}{l}\text { Xi'an; Xiangyang } \\
\text { Guiyang; Anshun } \\
\text { Chengdu; Meishan } \\
\text { Nanchang; Jiujiang }\end{array}$ & $\begin{array}{l}\text { Xi'xian } \\
\text { Gui'an } \\
\text { Tianfu } \\
\text { Ganjiang }\end{array}$ \\
\hline
\end{tabular}

The "territorial government" model is a complete coincidence of the power boundary between the functional and administrative zones of the NNA, i.e., a single administrative body simultaneously governs the economic and social affairs of the NNA. From a practical perspective, this model can be divided into "new district government" and "joint office" types. The former refers to the establishment of a district-level government for the NNA, with the approval of the State Council to exercise economic construction, social management, and public services within the scope of the NNA during its continuous development. This is the case in both the Pudong New Area after 2000 and the Binhai New Area after 2009. In Shanghai Pudong New Area [59] and Tianjin Binhai New Area, municipal districts under the municipality and directly under the control of central government have been established within the spatial scope of the NNAs. The municipal district government fully exercises the administrative, economic, and social management functions within the scope of the new districts. The administrative system of the "new district government" was not in place at the establishment of the NNA, but with the gradual development of the NNA into a new city, the main functions of the management body were transformed from promoting economic growth to the management of social affairs, which could only be realized through the adjustment of administrative divisions (Figure 5). 


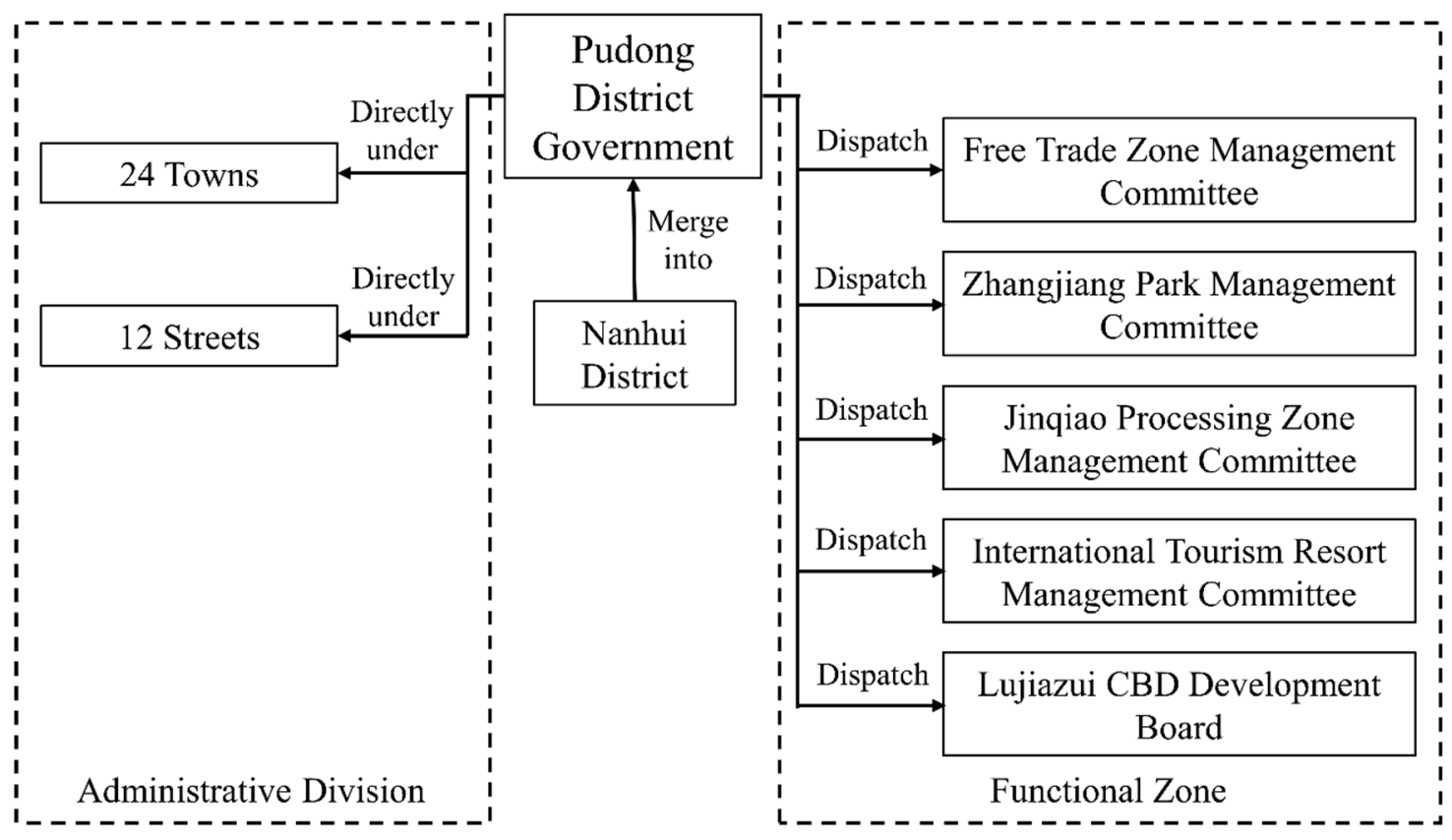

Figure 5. Administration of Pudong New Area in Shanghai (after 2000). Source. Author compiled from interviews in the fieldwork (August 2014) with local planners and officials.

"Joint office" is a term used to describe the situation when the planning scope of the NNA coincides with the scope of the administrative district. The administrative committee dispatched by the municipal government and the existing administrative government work together to implement "a set of people, two brands", while retaining the name of the original administrative region and the name of the NNA. Zhoushan Archipelago New Area (Figure 6) [60], Nansha New Area, West Coast New Area, and Jinpu New Area all have a "joint office" administrative system.

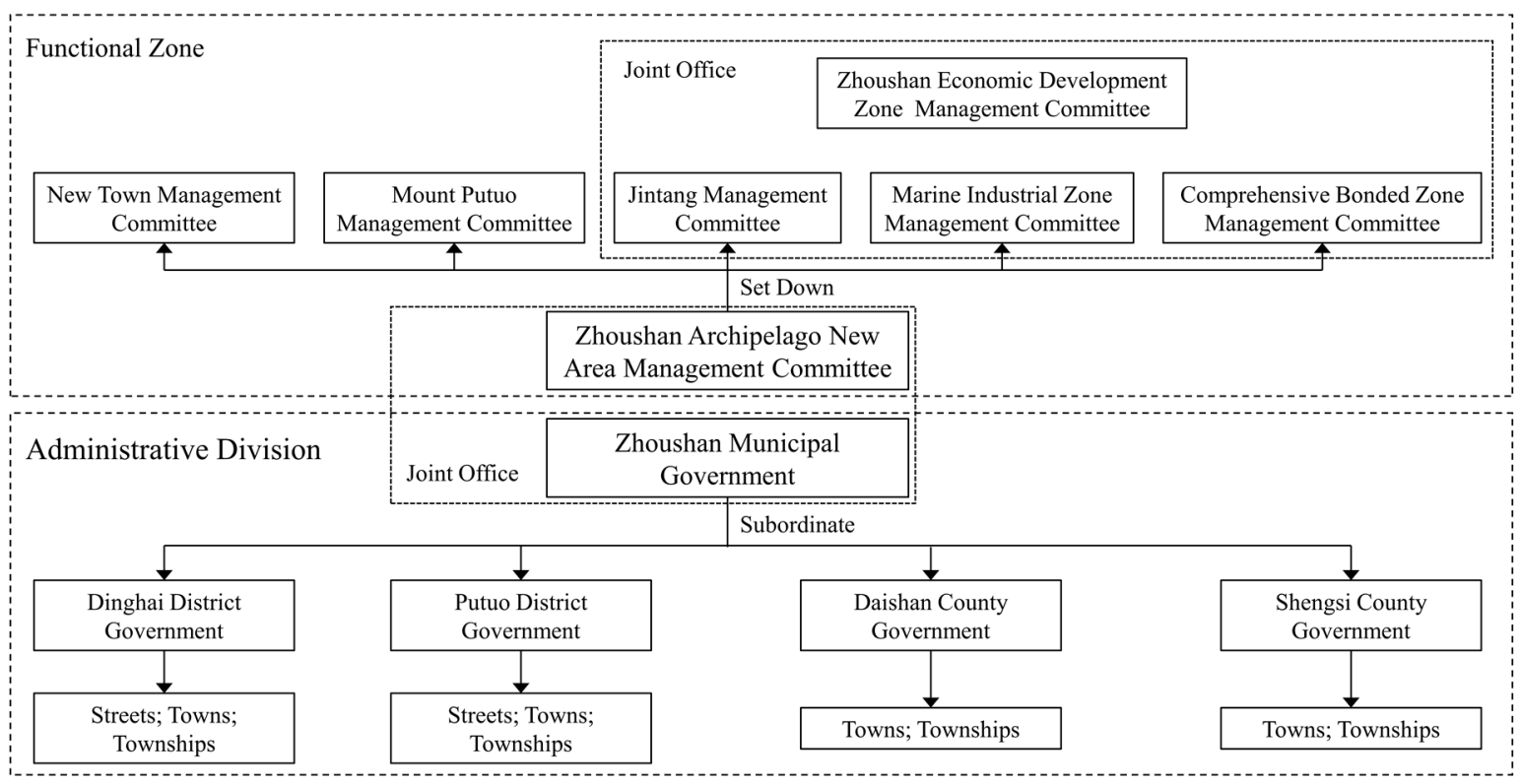

Figure 6. Administration of Zhoushan Archipelago New Area. Source. Author compiled from interviews in the fieldwork (July 2014) with local officials.

The "Management Committee" model refers to the establishment of a management committee by the municipal government (or municipalities directly under the central government) at the prefecture 
level. It acts as a dispatched agency to exercise the management of economic affairs, such as planning and construction, land development, and attracting investment on behalf of local governments, while maintaining the existing administrative bodies of the districts/counties involved in the NNA. However, the jurisdiction of social affairs is still mainly the responsibility of the original administrative subjects. Due to the diversity of spatial division and reconstruction of NNAs, the "Management Committee" model can be divided into three types in practice: Management Committee I, Management Committee II, and Management Committee III. The "Management Committee I" type is mostly applicable to the situation in which the spatial scope of the NNA is composed of municipal districts, while the "Management Committee II" type is mostly applicable to the situation in which the spatial scope of the NNA involves municipal counties. "Management Committee III" is mostly applicable to the spatial scope of NNAs that cross administrative boundaries of prefecture-level cities.

Because many large and medium-sized cities in China have already adjusted their administrative divisions by removing counties and establishing districts, "Management Committee I" type is the most commonly used system in NNAs, including Chongqing Liangjiang New Area, Nanjing Jiangbei New Area, Harbin New Area, and Changchun New Area. A municipal district is not a complete administrative unit, but is rather a dispatched agency of the city government. Under the current bureaucratic management system, communication between the city government and the municipal district is relatively smooth. For example, in the Chongqing Liangjiang New Area [61], the government of each municipal district entrusts economic development to the administrative committee of the new district, and only assumes the social management function itself, so as to "escort" the construction of the NNA (Figure 7). This institutional arrangement gives the Management Committee greater power, second only to the "New District Government" system used in Pudong New Area and Binhai New Area. At the appropriate time, the Management Committee can be directly transformed into a "New District Government".

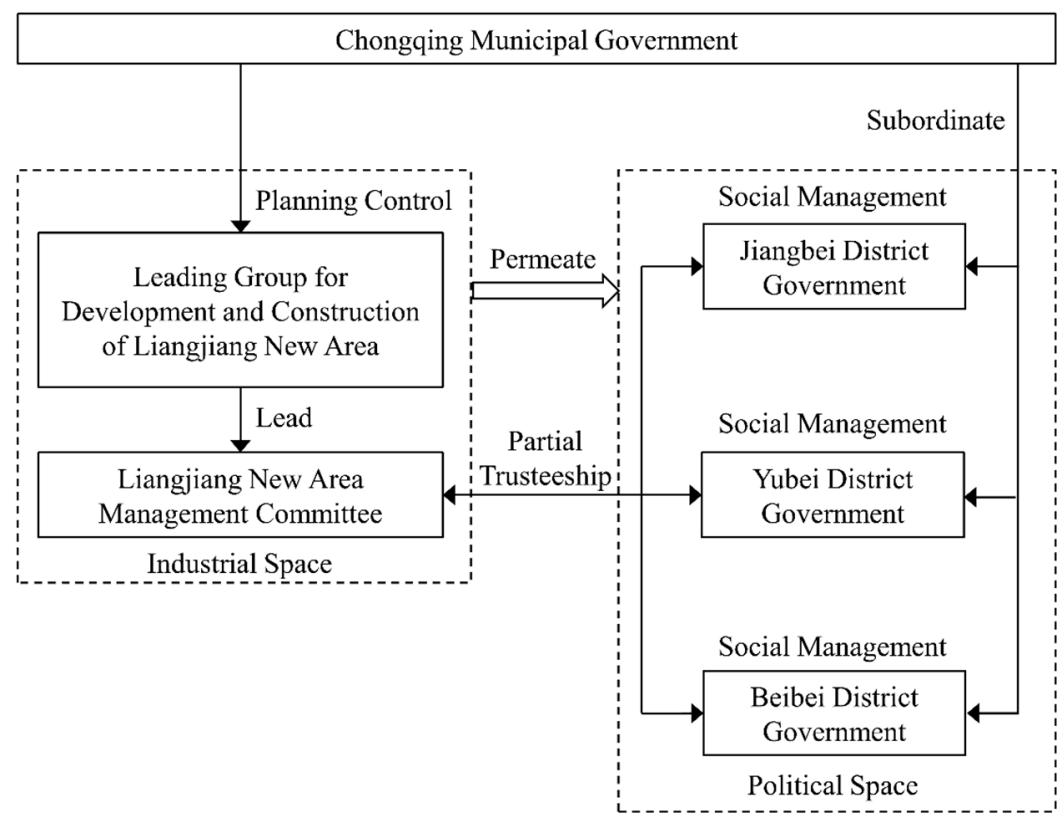

Figure 7. Administration of Chongqing Liangjiang New Area. Source. Author compiled from interviews in the fieldwork (2013-2016) with local planners and officials.

Municipal Counties are the most widely implemented local administrative management system in China. Many NNAs, including counties (county-level cities) under the jurisdiction of a prefecture-level city, are administered by the "Management Committee II" system, for example, Lanzhou New Area (Figure 8) [62], Xiangjiang New Area, Fuzhou New Area, and Dianzhong New Area. According to the Constitution of China, a county under municipal jurisdiction (county-level city) is a complete 
administrative unit. Therefore, although they are nominally managed by prefecture-level cities, counties (cities) still have relatively complete autonomy in urban development and construction. Under the Municipal County system, the management committee cannot bypass the county administrative region to directly exercise the right to development, and, therefore, the administrative divisions and the functional zones still operate in two parallel governance systems.

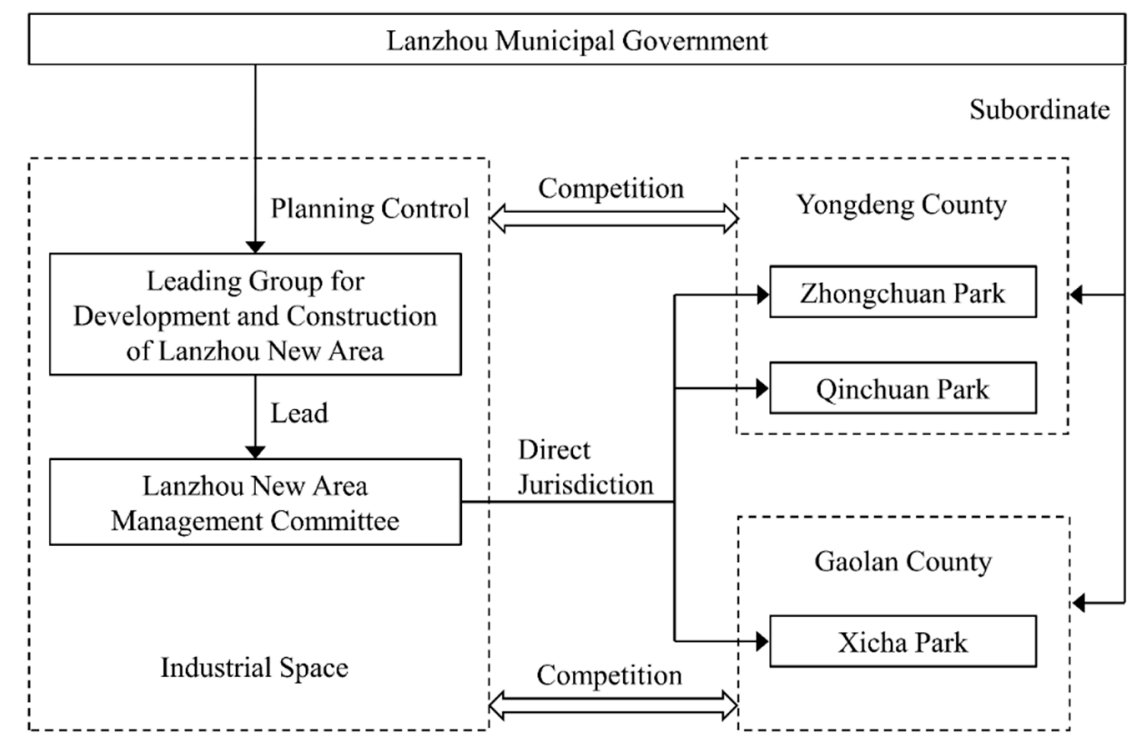

Figure 8. Administration of Lanzhou New Area. Source. Author compiled from interviews in the fieldwork (May 2017) with local planners and officials.

There are currently four NNAs that span the administrative boundaries of prefecture-level cities, namely, Shanxi Xi'xian New Area, Guizhou Gui'an New Area, Sichuan Tianfu New Area, and Jiangxi Ganjiang New Area. This kind of NNA needs the intervention of administrative power at the provincial level to reach a consensus on its development between prefectures and municipalities. Even with the macro-coordination of a higher government, the specific affairs are still implemented through the administrative, fiscal, and taxation systems of different prefecture-level cities. This governance structure makes it difficult to improve the administrative efficiency of functional zones, and has even caused the division of functional zones. For example, at the establishment of Xi'xian New Area [63], it was divided into Fengwei New Area under the management of Xi' an City and Jingwei New Area under the management of Xianyang City. The planning was divided into five functional zones (new towns). A New Zone (Town) Management Committee was established, which was under the dual leadership of Xi'xian New Area Management Committee and the municipal government, but was mainly managed by the municipal government. Under this governance structure, $\mathrm{Xi}^{\prime} \mathrm{xian}$ New Area has become two new areas of Xi'an and Xianyang, which is not conducive to unified development and construction (Figure 9). In January 2017, Xi'xian New area was incorporated into Xi'an, and its Management type changed from joint office to Management committee I. 


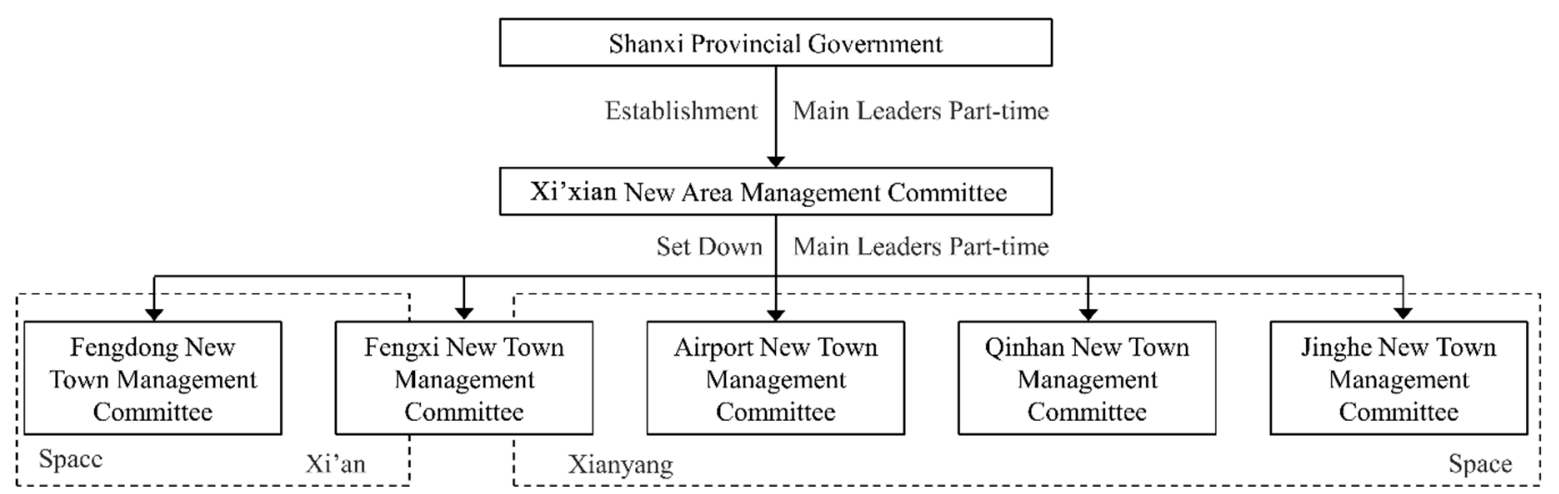

Figure 9. Administration of Xi'xian New Area (Before 2017). Source. Author compiled from interviews in the fieldwork (May 2017) with local planners and officials.

Prefecture-level cities, municipal districts, and municipal counties (or county-level cities) differ in their willingness and ability to develop as administrative units for their own development. Prefecture-level cities and municipal counties (or county-level cities) have more independent fiscal and taxation systems than municipal districts and have a stronger willingness and ability to develop. This means that different types of administrative systems are reconstructed in NNAs, and the complexity of the relationships between the administrative systems is also different (Table 3). In terms of actual development, the economic development of NNAs and their functional zones still needs to be implemented through the administrative, fiscal, and taxation systems of different prefecture-level cities or municipal counties.

\subsection{Reconstruction of the Power Allocation}

As a national strategic space directly approved and managed by the State Council, an NNA can gain authority and resources by scaling up (Figure 10). Regardless of the territorial government model or the management committee model, the administrative systems directly under the jurisdiction of the NNA have been decentralized by the central and provincial governments. However, the authority delegated by the higher government is mainly focused on development, construction, and economic management, while the authority with regard to social affairs mostly retains its original configuration. For example, after the establishment of Liangjiang New Area, the Chongqing Municipal Government coordinated the administrative bodies of municipal districts and functional zones by establishing administrative committees and taking the lead in high-level distribution. This endowed the administrative committees with sub-provincial authority in economic management, planning, construction, and land use [23].

On the other hand, by relying on a flexible institutional setting, the NNAs have also devolved the power of personnel, examinations, and approval to their internal functional zones (Figure 10). The economic vitality of each functional zone has been fully released by simplifying the examination and approval process and innovating the means of administration. This is mainly manifested in the weakening of regulatory means and in innovation with regard to planning. The weakening of regulation means that the jurisdiction role of an NNA is to effectively stimulate market vitality, generally narrow the scope of regulation, and weaken the government's control and restraint on economic development. The innovations in planning have resulted in the integration of functional departments and the invention of "new planning", and, therefore, NNAs have become the main means of power allocation.

However, as integrated territorial units, municipal districts and counties (or county-level cities) have the ability to develop independently and have the willingness and logic to safeguard their own developmental interests $[44,45]$. Although the main bodies involved in the jurisdiction of the NNA have been decentralized by the state and provinces and cities, there is an inevitable conflict with the administrative aims of other districts/counties (Figure 10). County administrative units 
have a particularly strong willingness and ability. Under the background of "expanding power and strengthening counties" and "directly administering counties by provinces", it is not easy to reach a development consensus between "municipality and county" or "county and NNA". Therefore, the extent to which the power allocation of an NNA can avoid conflicts with other districts/counties needs to be tested on the basis of development practices. For the districts/counties beyond the space involved in the NNA, there is an unequal competitive relationship between themselves and the NNA, but there are no power conflicts involved.

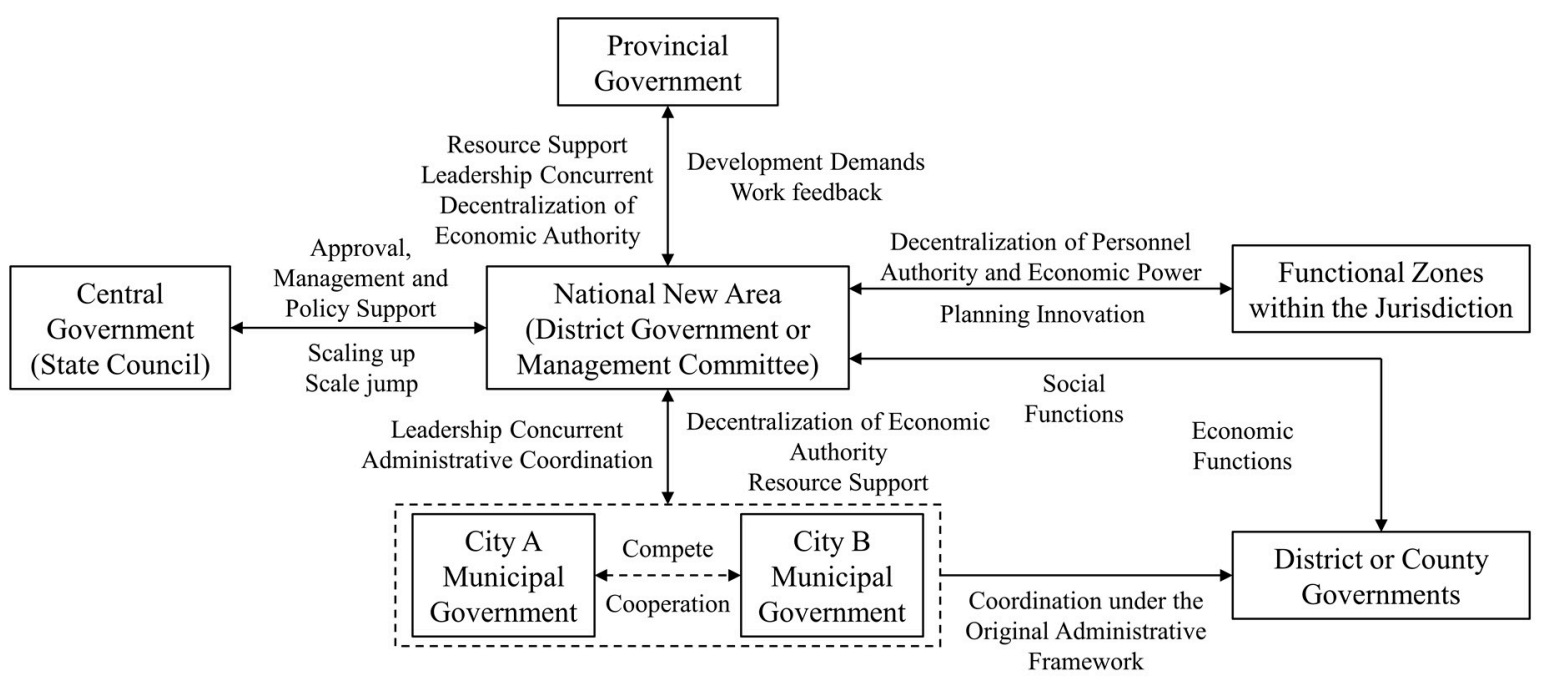

Figure 10. A schematic diagram of the power allocation relationship in a National New Area (NNA).

\section{Discussion: Key Factors and Challenges Influencing the Rescaling of NNA Governance}

In the era of globalization, and in the face of the "borderless" flow of global capital, state rescaling is conducted to accurately capture the opportunities of regional development and form regional development advantages [7,11]. The establishment of NNAs reflects the rescaling strategy of China to meet development challenges at home and abroad. For the rescaling of NNA governance, the overall goal of regional development should be achieved through the arrangement of functional orientation, spatial division, administrative systems, and power allocation. Whether an intensively approved NNA can achieve the goal of overall regional development or will intensify the vicious competition between regions requires further investigation.

To a certain extent, the establishment of NNAs can reconstruct the institutional framework and developmental trend of national strategic regions. Under the background of globalization, although the region has become the most suitable spatial unit for national capital accumulation, under the influence of marketization and decentralization, the "entrepreneurship" of local governments has weakened the overall ability of regions to a great extent. Despite the emergence of regional planning, with various themes and corresponding coordinating organizations at the regional level, due to the lack of internal demand coupling among members and the lack of necessary safeguards at the institutional level, competition within regions is still greater than cooperation. Therefore, the institutional framework of the national strategic region should reduce the vicious competition within regions to realize the low-cost and product differentiation strategies required for regional development. The source of the NNAs governing power is based on the scaling up provided by the special system of the state. The NNA has the authority provided by sub-provincial (or main office) management. Its establishment can reduce the vicious competition within a region and build an institutional framework of regional coordination and cooperation. On the one hand, the functional orientation of an NNA has high-end and strategic characteristics, making it the source and leader of economic and industrial development in the region. This will strengthen its radiation driving role and reduce the transaction costs in the regional industrial division network. On the other hand, because of the planning and approval of 
the functional orientation of NNAs by the State Council, their establishment reflects the national strategy, and the provinces and municipalities where they are located must decentralize the provincial management authority according to the national requirements. Therefore, the administrative system of an NNA essentially has the autonomy of sub-provincial management and is not restricted to the level of the original administrative unit within the NNA. This means that the rescaling of an NNA is generally a scaling-up process, i.e., from a low level to the sub-provincial scale.

The scale-up has improved the administrative level of the NNAs, but it has also increased the difficulty of governance reconstruction between the NNA and the administrative units in the region. The reconstruction of governance relationships in NNAs involves the newly established "new scale", i.e., how to position oneself in the local governance hierarchy, how to construct the relationships, and how to assume the governance functions. In this process, if the new scale is fully integrated into the original scale system to achieve a clear status, relationship, and functions, then the rescaling of the NNA will be successful. It currently seems that the path to achieve this goal is: (1) a rigid "new district government" as represented by Shanghai Pudong New Area and Tianjin Binhai New Area; (2) a "management committee I" type as represented by Liangiiang New Area; and (3) a flexible management committee as represented by the reformed Xi'xian New Area in Shaanxi Province. These three systems are best able to solve the conflict between the new and original scales; thus, strengthening the existing scale. It can be seen that the rescaling of NNAs has not only formed a new economic and social space but also a new governance scale in the existing administrative system of China. The degree of coupling between the new and original scales (i.e., the original administrative divisions) is the key factor that will determine the rescaling of NNA governance.

Considering the sensitivity of per capita GDP in measuring the development results, the change of per capita GDP is used to detect the development results of National New Areas (Figure 11). In most municipalities, the per capita GDP increment of the NNA within the same municipality is lower than that of the non-NNA. Obviously, the current spatial governance structure of most NNAs has failed to achieve the goal of fully integrating the new and original scales, which has resulted in major problems in the rescaling of NNA governance, including the diversification of governance systems and inconsistent territorial logic. In terms of the sub-national strategic space that the central government is attempting to cultivate, the original intention of the establishment of NNAs was to build a complete territorial organization and give it complete developmental control of territorial space through rescaling. However, the rescaling of most NNAs is still incomplete. Regardless of the rescaling of some administrative functions, as represented by the different types of management committee, or the rescaling of some administrative space, as represented by the use of the joint office system, the governance of new districts has not been fully unified. On the surface, the NNAs are independent territorial organizations, but they are in fact composed of the original capital territorialization platforms (prefectures, districts, counties, etc.) at various scales. Each territorial organization has its own territorial logic to safeguard its own interests. In the development and construction of NNAs, this has manifested itself in terms of the different assumptions and requirements for territorial development. To achieve the goal of accelerating the development of NNAs, it will be important to complete the governance construction as soon as possible through rescaling and unify the governance systems and territorial logic. 


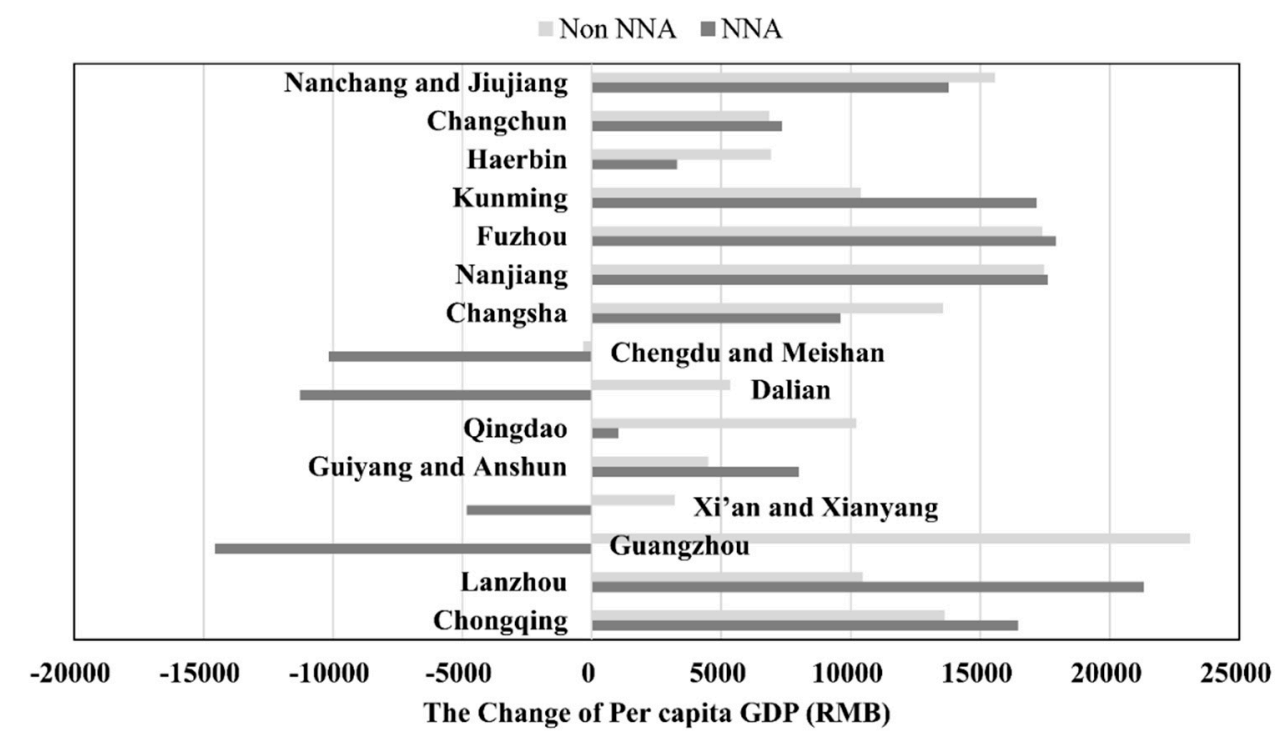

Figure 11. Comparison of the growth of per capita GDP between the NNA and the non-NNA in 15 municipalities $(T-T+2)$. Note: $T$ represents the year of establishment of NNA.

\section{Conclusions}

In the conditions of globalization, the rapid transfer of production technology and the cross-regional flow of capital [1] have resulted in western countries and China generally experiencing a far-reaching rescaling $[2-4,9,10]$. As an analytical concept, in the context of territorial reorganization under globalization, rescaling provides a valuable perspective for examining the integration and reconstruction of social relationships and governance structures attached to territorial space [34-40]. This study developed an analytical framework from the perspective of rescaling. It found that the construction of the governance scale of an NNA is a process of transformation of administrative bodies at all levels, through rigid or flexible means. It was found that the functional orientation, spatial zoning, administrative systems, and power allocation of NNAs were manifested in the reconstruction of territorial space and social space. From a practical perspective, the governance scales constructed by different NNAs had significant differences in terms of the organization of territorial space, composition of administrative bodies, and power distribution, forming two governance modes of "territorial government" and "management committee". The "territorial government" model could be divided into "new district government" and "joint office" modes, while the "management committee" model could be divided into "management committee I", "management committee II", and "management committee III" modes. However, there are still many challenges to overcome before NNAs can truly unify the logic of territorial development. It was found that the rigid governance of "new district government" or flexible governance of "joint office" and "management Committee I", which have been adopted by a few NNAs, can better solve the problems of ambiguous power boundaries and pluralistic governance systems. However, the construction of governance scale in most NNAs still faces problems associated with the diversification of governance systems and the inconsistency of territorial logic.

The establishment and development of NNAs is essentially a process of building new territorial organizations, with the aim of enhancing their competitiveness in undertaking the reterritorialization of global capital. The governance scale construction of NNAs has followed a mechanism of combining "scale up" and "scale down" processes. On the one hand, this reflects the decentralization and deregulation of state power, while on the other hand, it symbolizes the re-centralization and restoration of state power in specific areas. As a result, NNAs have become a new system of territorial organization, and have the characteristics of multiscale "nesting" at the micro level. However, each administrative unit has its own territorial logic to safeguard its own development interests, which is manifested in the demand for the development of their respective jurisdictions and specific strategic choices. 
Therefore, the governance scale constructed by NNAs has a complex relationship with the existing scale structure in its area, and there is a risk of fragmentation of spatial governance. Therefore, the key to the optimization of the future governance scale construction of NNAs lies in reducing the governance subject and unifying the regional logic. The main goal is to unify multiscale territorial organizations into one, or to reach a development consensus among many territorial organizations, so as to form a truly unified territorial logic. In practice, we can simplify the internal scale structure of an NNA by the timely promotion of the adjustment of administrative divisions, or by unifying the developmental rights of each administrative unit in the management committee through a comprehensive trusteeship. Shaping a unified and effective geographical platform of territorial capital regionalization is not only the main way to improve the governance capacity of NNAs but is also the fundamental reason for establishing an NNA.

In summary, from the perspective of rescaling, we can understand and analyze the scale of NNA governance, which will improve the analysis framework of rescaling at the micro level and also provide support for improving the governance capacity of NNAs. It should be noted that in addition to the five types of governance considered in this study, the processes and types of governance in reality may be more complex and diverse. In addition, it is very likely that an adjustment or evolution of governance types will occur in a relatively short period of time during the development of an NNA. In the future, with the intensive establishment of NNAs, their characteristics as "policy highlands" will become increasingly weaker, while their characteristics as "reform highlands" will become increasingly prominent, and the construction of their own advantages will increasingly rely on the improvement of governance capabilities. Therefore, in the future, it will be necessary to undertake in-depth case studies of individual NNAs, and to explore the processes, mechanisms, and effects of the construction and evolution of the governance scale of NNAs by means of multicase comparisons using qualitative and quantitative methods.

Author Contributions: Conceptualization, L.W. and H.C.; investigation, L.W. and H.C.; methodology, H.C.; resources, H.C. and G.L.; writing—original draft, L.W.; writing—review and editing, H.C. and G.L.

Funding: This research was funded by National Natural Science Foundation Project of China (No. 41801145 and 41842038).

Acknowledgments: The authors would like to thank the anonymous reviewers of sustainability and the editors of the Journal for their insightful comments. Special thanks go to Tao for his help in cartography and those who offer great help in the field work.

Conflicts of Interest: The authors declare no conflict of interest.

\section{References}

1. Lin, G.C.S.; Li, X.; Yang, F.F.; Hu, F.Z.Y. Strategizing urbanism in the era of neoliberalization: State power reshuffling, land development and municipal finance in urbanizing China. Urban Stud. 2015, 52, 1962-1982. [CrossRef]

2. Sassen, S. Losing Control? Sovereignty in an Age of Globalization; Columbia University Press: New York, NY, USA, 1996; p. 15.

3. Martin, R. Institutional approaches in economic geography. In A Companion to Economic Geography; Sheppard, E., Barnes, T.J., Eds.; Blackwell: Oxford, UK, 2000; pp. 77-94.

4. Swyngedouw, E. Authoritarian Governance, Power, and the Political of Rescaling. Environ. Plan. 2000, 18, 63-76. [CrossRef]

5. Qi, Y.; Liu, T.; Jiao, J. Implementation methods and economic impacts of national node strategies. J. Geogr. Sci. 2017, 3, 348-364. [CrossRef]

6. Gilbert, A. The new regional geography in English and French-speaking countries. Prog. Hum. Geogr. 1988, 12, 208-228. [CrossRef]

7. Brenner, N. Globalisation as reterritorialisation: The re-scaling of urban governance in the European Union. Urban Stud. 1999, 36, 431-451. [CrossRef] 
8. MacLeavy, J.; Harrison, J. New state spatialities: Perspectives on state, space, and scalar geographies. Antipode 2010, 42, 1037-1046. [CrossRef]

9. Park, B. State rescaling in non-Western contexts. Int. J. Urban Reg. Res. 2013, 37, 1115-1122. [CrossRef]

10. Wu, F.L. China's emergent city-region governance: A new form of state spatial selectivity through state-orchestrated rescaling. Int. J. Urban Reg. Res. 2016, 40, 1134-1151. [CrossRef]

11. Brenner, N. New State Spaces: Urban Governance and the Rescaling of Statehood; Oxford University Press: New York, NY, USA, 2004.

12. Bayirbağ, M. Continuity and change in public policy: Redistribution, exclusion and state rescaling in Turkey. Int. J. Urban Reg. Res. 2013, 37, 1123-1146. [CrossRef]

13. Heley, J. Soft spaces, fuzzy boundaries and spatial governance in post-devolution Wales. Int. J. Urban Reg. Res. 2013, 37, 1325-1348. [CrossRef]

14. Jessop, B. The State-Past, Present, Future; Polity Press: Cambridge, UK, 2016.

15. Varró, K. Re-politicising the analysis of "new state spaces" in Hungary and beyond: Towards an effective engagement with "actually existing neoliberalism". Antipode 2010, 42, 1253-1278. [CrossRef]

16. Vlad, M.; Manuel, W. State rescaling and economic convergence. Reg. Stud. 2019, 53, 462-477.

17. Harrison, J. Rethinking city-regionalism as the production of new non-state spatial strategies: The case of Peel Holdings Atlantic Gateway Strategy. Urban Stud. 2014, 51, 2315-2335. [CrossRef]

18. Pratchett, L. Local autonomy, local democracy and the 'new localism'. Political Stud. 2004, 52, 358-375. [CrossRef]

19. Jonas, A.; Moisio, S. City regionalism as geopolitical processes: A new framework for analysis. Prog. Hum. Geogr. 2018, 42, 250-370. [CrossRef]

20. National Development and Reform Commission of People's Republic of China (NDRCPRC). China's National New Areas Development Report; China Planning Press: Beijing, China, 2018.

21. Lim, K.F. State rescaling, policy experimentation and path-dependency in post-Mao China: A dynamic analytical framework. Reg. Stud. 2017, 51, 1580-1593. [CrossRef]

22. Xu, J.; Wang, J.J. Reassembling the state in urban China. Asia Pac. Viewp. 2012, 53, 7-20. [CrossRef]

23. Li, L. State rescaling and national new area development in China: The case of Chongqing Liangjiang. Habitat Int. 2015, 50, 80-89. [CrossRef]

24. Ngo, T.-W.; Yin, C.; Tang, Z. Scalar restructuring of the Chinese state: The subnational politics of development zones. Environ. Plan. 2017, 35, 57-75. [CrossRef]

25. Yang, J.; Li, Y.; Hay, I.; Huang, X.J. Decoding national new area development in China: Toward new land development and politics. Cities 2019, 87, 114-120. [CrossRef]

26. Xu, J.; Yeh, A.G.O. Re-building regulation and re-inventing governance in the Pearl River Delta, China. Urban Policy Res. 2012, 30, 385-401. [CrossRef]

27. Wang, L.; Shen, J.F. The challenge of spatial plan coordination in urban China: The case of Suzhou city. Urban Policy Res. 2017, 35, 180-198. [CrossRef]

28. Li, Y.; Wu, F.L. The emergence of centrally initiated regional plan in China: A case study of Yangtze River delta regional plan. Habitat Int. 2013, 39, 137-147. [CrossRef]

29. Xu, J.; Yeh, A.G.O. Governance and Planning of Mega-City Regions: An International Comparative Perspective; Routledge: New York, NY, USA, 2011.

30. You-tien, H. The Great Urban Transformation: Politics of Land and Property in China; Oxford University Press: New York, NY, USA, 2010.

31. Lefebvre, H. The Urban Revolution; University of Minnesota Press: Minneapolis, MN, USA, 2003.

32. Harvey, D. Social justice, postmodernism and the city. Int. J. Urban Reg. Res. 1992, 16, 588-601. [CrossRef]

33. Kipfer, S.; Saberi, P.; Wieditz, T. Henri Lefebvre: Debates and controversies. Prog. Hum. Geogr. 2013, 37, 115-134. [CrossRef]

34. Howitt, R. Scale and the Other: Levinas and Geography. Geoforum 2002, 33, 299-313. [CrossRef]

35. Smith, N. Geography, difference and the politics of scale. In Postmodernism and the Social Sciences; Doherty, J., Graham, E., Malek, M., Eds.; Palgrave Macmillan: London, UK, 1992; pp. 57-79.

36. Swyngedouw, E. Neither global nor local: 'Glocalization' and the politics of scale. In Spaces of Globalization: Reasserting the Power of the Local; Cox, K.R., Ed.; Guilford: London, UK, 1997; pp. 137-166.

37. Brenner, N. The limits to scale? Methodological reflections on scalar structuration. Prog. Hum. Geogr. 2001, 25, 591-614. [CrossRef] 
38. Cox, K.R. The problem of metropolitan governance and the politics of scale. Reg. Stud. 2010, 44, $215-227$. [CrossRef]

39. Klink, J. Development regimes, scales and state spatial restructuring: Change and continuity in the production of urban space in metropolitan Rio de Janeiro, Brazil. Int. J. Urban Reg. Res. 2013, 37, 1168-1187. [CrossRef]

40. Shen, J. Scale, state and the city: Urban transformation in post-reform China. Habitat Int. 2007, 31, $303-316$. [CrossRef]

41. Horak, M. State rescaling in practice: Urban governance reform in Toronto. Urban Res. Pract. 2013, 6, 311-328. [CrossRef]

42. Li, Z.; Xu, J.; Yeh, A.G.O. State rescaling and the making of city-regions in the Pearl River Delta, China. Environ. Plan. 2014, 32, 129-143. [CrossRef]

43. Ye, L. State-led metropolitan governance in China: Making integrated city regions. Cities 2014, 41, $200-208$. [CrossRef]

44. Cartier, C. What's territorial about China? From geopolitical narratives to the administrative area economy. Eurasian Geogr. Econ. 2013, 54, 57-77. [CrossRef]

45. $\mathrm{Xu}, \mathrm{J} . ;$ Yeh, A.G.O. Interjurisdictional cooperation through bargaining: The case of the Guangzhou-Zhuhai Railway in the Pearl River Delta, China. China Q. 2013, 213, 130-151. [CrossRef]

46. Jessop, B. The Crisis of the National Spatio-temporal Fix and the Tendential Ecological dominance of Globalizing Capitalism. Int. J. Urban Reg. Res. 2000, 24, 323-360. [CrossRef]

47. Mansfield, B. Beyond Rescaling: Reintegrating the "National" as a Dimension of Scalar Relations. Prog. Hum. Geogr. 2005, 29, 458-473. [CrossRef]

48. The State Council of People's Republic of China. Approval of the State Council for the Establishment of Pudong New Area in Shanghai; The State Council of People's Republic of China: Beijing, China, 1992; State Letter [1992], No.145.

49. The State Council of People's Republic of China. State Council's Opinions on Promoting the Development and Opening-up of Tianjin Binhai New Area; The State Council of People's Republic of China: Beijing, China, 2006; State Issue [2006], No.20.

50. Liu, Y.; Yue, W.; Fan, P.; Peng, Y.; Zhang, Z. Financing China's suburbanization: Capital accumulation through suburban land development in Hangzhou. Int. J. Urban Reg. Res. 2017, 40, 1112-1133. [CrossRef]

51. Zhang, X.; Lin, Y.; Wu, Y.; Skitmore, M. Industrial land price between china's pearl river delta and southeast asian regions: Competition or coopetition? Land Use Policy 2017, 61, 575-586. [CrossRef]

52. Long, H.; Liu, Y.; Hou, X.; Li, T.; Li, Y.R. Effects of land use transitions due to rapid urbanization on ecosystem services: Implications for urban planning in the new developing area of China. Habitat Int. 2014, 44, 536-544. [CrossRef]

53. Liang, Z.; Chao, Y. Disorder or Reorder? The Spatial Production of State-Level New Areas in China. Sustainability 2018, 10, 3628.

54. National Development and Reform Commission of People's Republic of China (NDRCPRC). An Opinion on Promoting a Healthy Development of the National New Area; National Development and Reform Commission of People's Republic of China (NDRCPRC): Beijing, China, 2015; Fagai Issue [2015], No.778.

55. Zou, Y.; Zhao, W. Making a New Area in Xiong'an: Incentives and Challenges of China's "Millennium Plan". Geoforum 2018, 88, 45-48. [CrossRef]

56. The State Council of People's Republic of China. Approval of the State Council for the Establishment of Lanzhou New Area; The State Council of People's Republic of China: Beijing, China, 2012; State Issue [2012], No.104.

57. The State Council of People's Republic of China. Approval of the State Council for the Establishment of Nanjing Jiangbei New Area; The State Council of People's Republic of China: Beijing, China, 2015; State Issue [2015], No.103.

58. The State Council of People's Republic of China. Approval of the State Council for the Development Planning of Guangzhou Nansha New Area; The State Council of People's Republic of China: Beijing, China, 2012; State Issue [2012], No.128.

59. The Official Website of Pudong New Area. Available online: http://www.pudong.gov.cn/shpd/ (accessed on 8 June 2019).

60. The Official Website of Zhoushan Archipelago New Area. Available online: http://www.zhoushan.cn/rdzz/ gjjhhzhkf/ (accessed on 12 May 2019). 
61. The Official Website of Liangjiang New Area. Available online: http://www.liangjiang.gov.cn/ (accessed on 3 August 2019).

62. The Official Website of Lanzhou New Area. Available online: http://www.lzxq.gov.cn/ (accessed on 23 May 2019).

63. The Official Website of Xi'xian New Area. Available online: http://www.xixianxinqu.gov.cn/ (accessed on 15 June 2019).

(C) 2019 by the authors. Licensee MDPI, Basel, Switzerland. This article is an open access article distributed under the terms and conditions of the Creative Commons Attribution (CC BY) license (http://creativecommons.org/licenses/by/4.0/). 